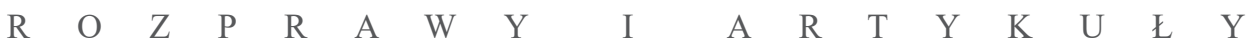

PAMIĘTNIK TEATRALNY 2020/4 (276)

ISSN 0031-0522, e-ISSN 2658-2899

INSTYTUT SZTUKI PAN

DOI: $10.36744 /$ pt. 132

\title{
Halina Waszkiel
}

Akademia Teatralna im. Aleksandra Zelwerowicza w Warszawie

ORCID: 0000-0003-0302-6620

\section{WARSZAWSKI HAMLET 1871 \\ DYLEMATY HISTORIOGRAFICZNE}

Hamlet in Warsaw 1871:

Historiographic Dilemmas 


\begin{abstract}
Abstrakt: Artykuł dotyczy premiery Hamleta zrealizowanej w Teatrze Wielkim w Warszawie 24 marca 1871 na benefis Heleny Modrzejewskiej, przedstawienia uważanego za ważny rozdział historii teatru warszawskiego w drugiej połowie XIX wieku. Podjęto próbę oddzielenia dokumentów z epoki od późniejszych interpretacji, by skomplikować i sproblematyzować obraz tej legendarnej inscenizacji nakreślony przez Józefa Szczublewskiego w latach sześćdziesiątych XX wieku. Praca nad materiałami otworzyła możliwość dyskusji o migotliwości faktów, mechanizmie powstawania legend teatralnych oraz dylematach związanych z opisem i oceną historycznych zjawisk teatralnych. Istotnym wątkiem podjętej w artykule analizy historiograficznej jest również próba problematyzacji napięcia między literaturocentrycznym i teatrocentrycznym nastawieniem do badań teatralnych.
\end{abstract}

Słowa kluczowe: Shakespeare, Hamlet, Teatr Wielki w Warszawie, Helena Modrzejewska, Jan Chęciński, Jan Królikowski, Alojzy Gonzaga Żółkowski, Krystyn Ostrowski, historiografia teatru, inscenizacja dziewiętnastowieczna

Abstract: This article discusses the performance of Hamlet that premiered at Teatr Wielki [Grand Theater] in Warsaw on 24th March 1871. Produced as part of the celebrations of Helena Modrzejewska's achievement, it is regarded as an important chapter in the history of Warsaw theater in the second half of the 19th century. The author separates historical documents dating from the period in question from later interpretations in order to complicate and problematize the image of this legendary staging created by Józef Szczublewski in the 1960s. Research using archive materials enables a discussion of the instability of facts, the mechanism of creating theater legends, and the dilemmas concerning the description and evaluation of historical phenomena. An important part of the historiographic analysis undertaken in the article is also to problematize the tension between a literature-oriented and theatre-oriented approach to studying theater history. (Trans. Z. Ziemann)

Keywords: Shakespeare, Hamlet, Grand Theater in Warsaw, Helena Modrzejewska, Jan Chęciński, Jan Królikowski, Alojzy Gonzaga Żółkowski, Krystyn Ostrowski, theater historiography, 19th-century staging 
W arszawski Hamlet z 1871 roku zajmuje w historii polskiego teatru wysoką pozycję, a jednak intryguje niejednoznacznością. Przedstawienie zostało dość szczegółowo opisane w dotychczasowych pracach, zwłaszcza Józefa Szczublewskiego ${ }^{1}$. Podstawowe informacje dotyczące okoliczności powstania spektaklu, przebiegu premiery, teatralnego kształtu przedstawienia (scenografia, kostiumy, muzyka, obsada) oraz szereg cytatów z ówczesnej prasy dokumentujących reakcję krytyków teatralnych i felietonistów zebrałam niedawno w poświęconym tej inscenizacji haśle w Encyklopedii Teatru Polskiego ${ }^{2}$. Praca nad wielowarstwowym palimpsestem, jaki tworzy wyjątkowo bogata dokumentacja historyczna przedstawienia, stała się impulsem do podjęcia próby oddzielenia tego, co wynika z dokumentów epoki, od późniejszych interpretacji, a także okazją do refleksji nad wieloma historiograficznymi dylematami.

Na dokumentację premiery składają się różnogatunkowe materiały: zachowany cudem egzemplarz reżyserski Jana Chęcińskiego ${ }^{3}$, Album Modrzejewskiej ${ }^{4}$, wzmianki w listach i wspomnieniach oraz wiele recenzji, zarówno w najważniejszych periodykach: „Kłosach”, „Tygodniku Ilustrowanym”, „Gazecie Warszawskiej”, „Bluszczu”, „Dzienniku Warszawskim”, „Kurierze Warszawskim”, „Kurierze Codziennym”, jak i w czasopismach pomniejszych, jak „Kurier Świąteczny”, „Tygodnik Mód” czy „Opiekun Domowy”. Mamy nawet fotografie - nieliczne, ale cenne: Modrzejewskiej w roli Ofelii oraz Józefa Damsego jako jednego z Grabarzy ${ }^{5}$. Czy jednak na podstawie istniejących materiałów nasza wyobraźnia

1 J. Szczublewski, Warszawski scenariusz „Hamleta” z 1871 roku, „Pamiętnik Teatralny” 1962 z. 1; idem, Nieznany rękopis Heleny Modrzejewskiej, „Pamiętnik Teatralny” 1955 z. 1; idem, Wielki i smutny teatr warszawski 1868-1880, Warszawa 1963 (cytaty za wyd. rozszerzonym z 2015).

2 H. Waszkiel, William Shakespeare. „Hamlet” 1871, http://encyklopediateatru.pl/przedstawienie/71348/hamlet [dostęp: 18 VIII 2020].

3 Scenariusz - Hamlet, egzemplarz reżyserski Chęcińskiego, Zbiory Specjalne Instytutu Sztuki PAN, nr inw. 1885. Chęciński nanosił notatki na lwowskie wydanie dramatu: Hamlet, królewic duński, dramat w pięciu aktach W. Szekspira, przeł. K. Ostrowski, Lwów 1870, https://polona.pl/item/hamlet-krolewicdunski-dramat-w-5-aktach-w-szekspira,MTczNDI2MzI/4/\#info:metadata [dostęp: 10 XI 2020].

4 Album Modrzejewskiej, ozdobny zeszyt z notatkami artystki z lat 1866-1876, jej rozprawką Aktor i przepisanymi wierszami do recytacji, Pracownia Dokumentacji Teatru Instytutu Sztuki PAN, Zbiory Dawne 84; druk: J. Szczublewski, Nieznany rękopis..., op. cit.

5 Zob. H. Waszkiel, op. cit. 
może zrekonstruować zdarzenie teatralne, jakim było przedstawienie według Williama Shakespeare'a Hamlet, „tragedia w 5 aktach, 12 obrazach”, którego premiera odbyła się 24 marca 1871 w Teatrze Wielkim w Warszawie, na benefis Heleny Modrzejewskiej, z wykorzystaniem przekładu Krystyna Ostrowskiego, muzyką Stanisława Moniuszki i w reżyserii Jana Chęcińskiego?

Dlaczego tak wiele o Hamlecie 1871 pisano? Czy dlatego że było to wybitne przedstawienie, czy też z innych względów? Popremierowe omówienia prasowe miewały po kilka szpalt lub drukowane były w odcinkach. Nic więc dziwnego, że o Hamlecie 1871 wspominano później wielokrotnie w polskiej literaturze szekspirologicznej. Występ Heleny Modrzejewskiej w roli Ofelii zapewnił inscenizacji miejsce w niemałej już bibliotece prac poświęconych aktorce. Przyczynił się do tego Józef Szczublewski, który przy każdej okazji podkreślał, że wystawienie Hamleta $\mathrm{w}$ Warszawie było jej zasługą. W książce Wielki $i$ smutny teatr warszawski $1868-1880^{6}$ wyróżnił tę premierę, poświęcając jej cały rozdział. Szczublewskiemu zawdzięczamy również publikację Albumu Modrzejewskiej oraz szczegółowe omówienie egzemplarza reżyserskiego Chęcińskiego ${ }^{7}$. Fotografie Ofelii z krakowskiej i warszawskiej inscenizacji zamieszczono w wielu publikacjach ${ }^{8}$. W efekcie premiera Hamleta z 1871 została uznana za jedno z najważniejszych wydarzeń teatralnych w dziewiętnastowiecznych dziejach Teatrów Warszawskich. Autorytet Szczublewskiego sprawił, że wierzono mu na słowo, bez ponownego sięgania do źródeł.

Warto dziś zatem sprawdzić, co wynika z komentarzy sprzed półtora wieku, a co zostało na nich nadpisane przez późniejszych badaczy. Fakty historyczne są - jak wiadomo - migotliwe, każda opowieść jest czyjąś narracjąa ${ }^{9}$ a w przypadku teatru, którego dzieła nie istnieją, nie ma i nie może być żadnej „twardej prawdy”. Tym bardziej ciekawi proces rodzenia się legend teatralnych, wśród których legenda Hamleta 1871 jest jedną z największych.

\footnotetext{
6 J. Szczublewski, Wielki i smutny teatr..., op. cit.
}

7 Idem, Warszawski scenariusz..., op. cit.

8 Zachowały się fotografie Modrzejewskiej-Ofelii zarówno z inscenizacji krakowskiej (prem. 30 XI 1867, fot. Walery Rzewuski), jak i warszawskiej (fot. Jan Mieczkowski). Zdjęcia Modrzejewskiej jako Ofelii znajdują się w zbiorach m.in. Biblioteki Naukowej PAN i PAU w Krakowie, Biblioteki Narodowej, Muzeum Teatralnego; były wielokrotnie publikowane, zob. np.: Teatr polski od 1863 roku do schytku XIX wieku, red. T. Sivert, E. Heise, Warszawa 1982; Z miłości do sztuki. Helena Modrzejewska (1840-1909) / Helena Modjeska (1840-1909): For the Love of Art, red. A. Kowalska, oprac. M. Niezabitowski, Kraków 2009 (s. 116, 118, 119, 121, 122, szczególnie staranne reprodukcje).

9 Dyskutowano o tym na konferencjach „Nowe Historie” zorganizowanych przez Instytut Teatralny im. Z. Raszewskiego wraz z Katedrą Dramatu UJ w latach 2009-2011, zob.: Ustanawianie historii, red. A. Adamiecka-Sitek, D. Buchwald, D. Kosiński, Warszawa 2010; Wymowa faktów, red. A. Adamiecka-Sitek, D. Buchwald, Warszawa 2011; Poetyka kulturowa polskiego Szekspira, red. eaedem, Warszawa 2011; Nowe biografie, red. eaedem, Warszawa 2012. 


\section{TAJEMNICA WYBORU PRZEKŁADU}

Pierwszą zagadkę w tej legendzie stanowi wybór przekładu, zagrano bowiem kuriozalną wersję sztuki. W 1871 istniało kilka pełnych tłumaczeń Hamleta na język polski, od propozycji Wojciecha Bogusławskiego (z przełomu 1797/1798) po używany do dziś tekst Józefa Paszkowskiego (1862). Wybrano jednak przekład Krystyna Ostrowskiego (1811-1882), uczestnika powstania listopadowego, od 1831 przebywającego na emigracji w Paryżu. Na karcie tytułowej jego tłumaczenia Hamleta, wydanego we Lwowie w $1870^{10}$, znalazła się drukowana adnotacja: „Całkowity nakład 750 egzemplarzy oddany na rzecz szkoły dramatycznej we Lwowie [...] Z wyraźnym zastrzeżeniem wolności przedstawienia”, na następnej zaś drukowana dedykacja: „Obywatelstwu Miasta Lwowa to ostatnie dzieło poświęca - K. O.”. W egzemplarzu książki, na którym pracował Jan Chęciński, na górze strony tytułowej widnieje odręczna dedykacja piórem: „Dla Sceny Warszawskiej / Tłumacz / Krystyn Ostrowski" "11, a więc do Warszawy druk trafił z rąk tłumacza. Decyzji o wyborze przekładu nie podjął jednak Chęciński, skoro 16 sierpnia 1870 pisał do Modrzejewskiej:

Z Hamletem będzie trochę biedy, Królikowski ma grać główną rolę - zapewne zechce przekładu Krystyna Ostrowskie go, tymczasem Pani umie już rolę podług P a s zk ow s ki e g o i ten też przekład mamy w cenzurze ${ }^{12}$.

Jeśli decyzja należałaby do Modrzejewskiej, prawdopodobnie wybrałaby wersję Paszkowskiego - z kilku powodów. Po pierwsze, pół roku wcześniej (premiera 12 stycznia 1870) odniosła w Warszawie olśniewający sukces jako Julia w tragedii Shakespeare'a w przekładzie tego autora. Po drugie, także w jego przekładzie grała Ofelię w Krakowie i taką wersję tekstu znała na pamięć. Po trzecie, wielbiła Shakespeare'a i potrafiła ocenić wady i zalety różnych tłumaczeń. Zachował się egzemplarz roli Ofelii ${ }^{13}$ z zapisaną datą próby czytanej 1 lutego 1871. Są tam dopiski aktorki w rodzaju: „Pan Ostrowski przerabia Shakespeara”, „Pan Ostrowski improwizuje", są pytajniki zdradzające wątpliwości i komentarz przy piosnce Ofelii: „Te wiersze do Shakespearowskich podobne jak pięść do nosa”"14. Modrzejewska bardzo chciała zagrać Ofelię w Warszawie, wyuczyła się więc przekładu

105 III 1871 we Lwowie odbyła się premiera Hamleta, w której wykorzystano ten przekład.

11 Scenariusz - Hamlet, op. cit.

12 Korespondencja Heleny Modrzejewskiej i Karola Chtapowskiego, t. 1, wybór i oprac. J. Got, J. Szczublewski, Warszawa 1965, s. 163, http://www.encyklopediateatru.pl/ksiazka/383/korespondencja-heleny-modrzejewskiej-i-karola-chlapowskiego-t-1-1859-1880-wybor-i-oprac-jerzy-got-jozefszczublewski/strona/179 [dostęp: 10 XI 2020].

13 Muzeum Narodowe w Krakowie, sygn. MNK 732/11, cyt. za: D. Jarząbek-Wasyl, Za kulisami. Narodziny przedstawienia w teatrze polskim XIX wieku, Kraków 2016, s. 471.

14 Ibidem. 


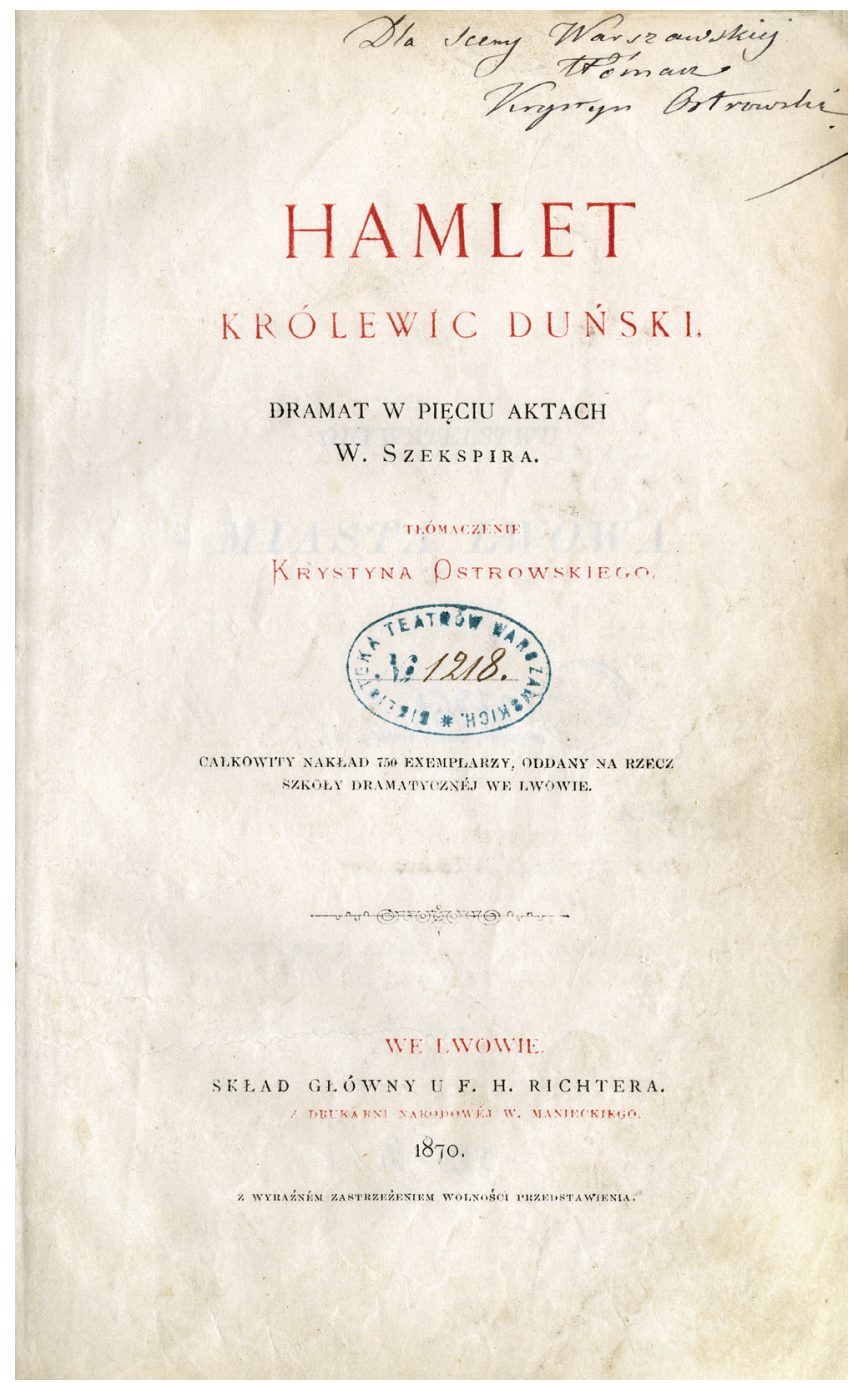

Hamlet, strona tytułowa egzemplarza reżyserskiego Jana Chęcińskiego z dedykacją thumacza, Krystyna Ostrowskiego, Zbiory Specjalne Instytutu Sztuki PAN. Fot. Krzysztof Piłat

Ostrowskiego. Krytyczne komentarze potwierdzają jednak, że nie jej głos był tu zasadniczy, choć przecież chodziło o jej benefis.

Czy w tej sprawie przeważył głos Królikowskiego, jak sugeruje Szczublewski, trudno dziś rozstrzygnąć. Nie można przecież wykluczyć, że o wyborze przekła$\mathrm{du}$, jak i o wszystkich sprawach repertuarowych, zdecydował prezes Muchanow. 
Może sądził, że pozyska przychylność polskiej publiczności, pozwalając na polonofilskie dziwactwa Ostrowskiego? Przypomnijmy w skrócie, że Ostrowski zrobił z Poloniusza jeńca pojmanego w Polsce i wykreował go na dumnego Sarmatę, Ofelia - też Polka, skoro córka Poloniusza - śpiewała na ludową, polską nutę. Laertes również szczycił się polskim pochodzeniem, a Hamlet wyznawał: „radbym być Polakiem" ${ }^{15}$. Szczublewski podkreślał, że gdyby nie ocalały egzemplarz reżyserski, wniosek, „że znany z patriotyzmu Królikowski akurat ze względu na polskie akcenty wybrał przekład Ostrowskiego, byłby całkiem logiczny" "16. Chęciński bowiem, wycinając z tekstu tysiąc siedemset wierszy, wyrzucił większość dziwacznych spolszczeń ${ }^{17}$. Do zastanowienia skłania jednak w tym kontekście zmiana zakończenia tragedii, z którego wykreślono postać Fortynbrasa. Gdy Hamlet umiera, pojawia się Duch ojca, pochyla się nad synem, po czym znika. Reżyser, usuwając wymyśloną przez Ostrowskiego kwestię Ducha: „Hamlecie, wolnym jesteś - Tam, do Boga!", kończy tę scenę - i całą sztukę - słowami Horacego: „Męczennik ojciec niebo ci otwiera” ${ }^{18}$. Słowa te musiały mieć wstrząsającą moc, wypowiadane ze sceny w 1871, gdy rany po klęsce powstania styczniowego były jeszcze bardzo świeże. Może dla zaakcentowania tego zdania - że męczeństwo ojców otwiera niebo potomnym - warto było wystawić Hamleta w przekładzie Ostrowskiego?

W recenzjach dominował jednak ton krytyki tłumaczenia. Józef Kenig, w obszernym, rozłożonym na pięć numerów „Gazety Warszawskiej” omówieniu Hamleta, napisał, że jest to przekład „,najgorszy z istniejących”, a szczególnie nieznośny - w partiach wierszowanych, gdzie „dla rytmu i niewolniczej wierności słowa, nie zaś myśli, poświęcono koloryt poetyczny i wdzięczną prostotę wysłowienia, a nawet gramatyczną poprawność mowy" ${ }^{19}$. Podobnie uważał recenzent „Bluszczu” Edward Lubowski:

Przekład ten dokonany białym wierszem, gdzieniegdzie rymem, raził w wielu miejscach ucho brakiem zaokrąglenia, twardością i szorstkością rytmiczną, a nawet niestosownością czy to porównań obrazowych, czy wprost wyrażeń sadzących się na swojskość, w tym razie wcale niesmaczną. [...] Brak [...] poetyczności [tłumacz] zastąpić chciał prostotą, która atoli przerodziła się w gminność i trywialność ${ }^{20}$.

15 Scenariusz - Hamlet, op. cit., s. 117.

16 J. Szczublewski, Warszawski scenariusz..., op. cit., s. 126.

Ibidem, s. 127-128.

18 Scenariusz-Hamlet, op. cit., s. 169.

19 [J. Kenig], Teatr Wielki. Hamlet. Tragedya w 5-u aktach Szekspira, „Gazeta Warszawska” 1871 nr 93, s. 3, https://crispa.uw.edu.pl/object/files/335096/display/Default [dostęp: 18 VIII 2020].

20 E. Lubowski, Przeglad teatralny, „Bluszcz” $1871 \mathrm{nr}$ 14, s. 111, https://polona.pl/item/bluszczpismo-tygodniowe-illustrowane-dla-kobiet-r-6-t-7-nr-14-5-kwietnia-1871,NDc2OTE1MTM/6/\#info: metadata [dostęp: 18 VIII 2020]. 
Fryderyk Henryk Lewestam, którego prelekcję i recenzję opublikowały „Kłosy”, oskarżył tłumacza o „niemiłosierne kaleczenie arcydzieła Shakespeare'a” i zarzucił mu „brak dobrego smaku pod względem wersyfikacji, nieumiejętne władanie językiem i niedołęstwo w pojmowaniu niektórych, najbardziej właśnie ujmujących ustępów oryginału" ${ }^{21}$. Najwyraźniej w latach siedemdziesiątych XIX wieku dla krytyki ważny już był oryginalny Shakespeare.

Jak widzieli sprawę późniejsi badacze? Dominuje opinia Szczublewskiego, który był przekonany, że decyzja o wyborze przekładu Ostrowskiego należała do Królikowskiego, a upór aktora mógł wynikać

z jakichś prywatnych zobowiązań Królikowskiego względem Ostrowskiego (który mógł przecież podjąć trud tłumaczenia z myślą o Królikowskim), czy też ów odrzucał przekład Paszkowskiego jako wykorzystany już przed trzema laty na scenie krakowskiej, gdzie Hamleta grano „W układzie tekstu” opracowanym przez Rapackiego i z Rapackim w roli tytułowej22.

Ostatnią tezę potwierdzałby komentarz Marii Faleńskiej, która tak wyjaśniała Karolowi Estreicherowi sytuację Rapackiego w Warszawie:

Sam już wybór sztuk do wystąpień, i tak u nas mały, bardziej jeszcze jest utrudniony koteryjnymi względami, i tak jeśli na jedną sztukę nie zgadza się cenzura, to na drugą znowu nie pozwalają względy należne Królikowskiemu, którego własnością wyłączną zdaje się być każda rola przez niego grywana ${ }^{23}$.

Szczublewski stwierdził autorytatywnie, że „sprawę przesądził Królikowski, a Chęciński i Modrzejewska musieli dostosować się do jego wyboru"24. Dlaczego jednak „musieli”? Jeśli jakiś udział w całej sprawie miały ukryte względy patriotyczno-polityczne, a decyzja skreślenia większości fragmentów polonofilskich była jednak formą autocenzury Chęcińskiego albo rezultatem obaw Muchanowa, to dlaczego Królikowski zaakceptował tak daleko idące zmiany w tekście? A może wcale nie chodziło o względy polityczne, lecz artystyczne. I Chęciński, i Modrzejewska, i wyedukowani krytycy zbyt wysoko cenili Shakespeare'a, by ze względów patriotycznych zgodzić się na dziwactwa kaleczące arcydzieło. Czyżby Królikowski tych mankamentów nie widział, pragnąc za wszelką cenę zagrać inną wersję Hamleta niż konkurent Rapacki, zaangażowany do zespołu Dramatu Teatrów Warszawskich 3 lutego 1870? Materiały z epoki nie ułatwiają rozstrzygnięcia tej kwestii. Lepiej więc zostawić ją otwartą.

21 F. H. L. [F. H. Lewestam], Teatr. Hamlet, tragedya Shakespeare 'a, „Kłosy” $1871 \mathrm{nr} 301$, s. 219 , https://polona.pl/item/klosy-czasopismo-illustrowane-tygodniowe-1871-t-12-nr-301-6-kwietnia,OTI4 ODEzODQ/10/\#item [dostęp: 18 VIII 2020].

22 J. Szczublewski, Warszawski scenariusz..., op. cit., s. 126.

23 Z. Jasińska, Na scenie teatru i życia. Saga rodu Leszczyńskich-Rapackich, Warszawa 2010, s. 39.

24 J. Szczublewski, Warszawski scenariusz..., op. cit., s. 126. 


\section{HAMLET Z KIEPSKIM HAMLETEM?}

Królikowski w roli Hamleta od początku budził kontrowersje. Lepszym kandydatem wydawał się właśnie Rapacki, który w 1867 odniósł w tej sztuce sukces w Krakowie, występując z Modrzejewską jako Ofelią u boku. Miał wówczas dwadzieścia siedem lat, a jego „wystudiowany samodzielnie” Hamlet „młody wątły chłopiec, idealista, w którym głęboka refleksja łączy się naturalnie z żywością i swobodą ruchów. Robił duże wrażenie" - jak ustaliła Zofia Jasińska ${ }^{25}$. W 1871 Rapacki miał lat trzydzieści jeden, a Królikowski - pięćdziesiąt jeden.

W sprawie obsadzenia tytułowej roli Chęciński zdał się na Muchanowa. W liście do prezesa pisał:

Rola Hamleta została wpisana dwóm osobom, to jest Królikowskiemu i Rapackiemu. O ile wiadomo, Królikowski od dawna wzdycha do tej roli, Rapacki także pragnie ją grać, tym bardziej, że grał w Krakowie i z powodzeniem. Zapewne ostateczne słowo JWy Pan wyrzecze albo też rozkaże dublowanie, na czym sztuka, a może więcej kasa, nie straci ${ }^{26}$.

Może zatem Muchanow wskazał na mocno osadzonego w warszawskim zespole Królikowskiego, by uniknąć konfliktów? Jeśli tak było, popełnił błąd, bo Hamlet Królikowskiemu się nie udał.

Chociaż Modrzejewska wspominała: „Publiczność niemal szalała z zachwytu nad grą p. Królikowskiego"27, to w recenzjach dominowała nuta krytyczna. Wydaje się, że łagodził ją tylko szacunek dla zasłużonego aktora. Recenzent „Tygodnika Mód" deklarował:

Główną rolę Hamleta grał pan Królikowski, co zdaje się być dostatecznym do przekonania, że oddaną była z całym wniknieniem i zrozumieniem duszy bohatera, tak jak go sam Szekspir zapewne pojął i zrozumiał ${ }^{28}$.

Z zasady mało krytyczny „Kurier Warszawski” chwalił „niepospolity talent aktora”29, „Kurier Codzienny” - podobnie ${ }^{30}$. Ale już Wacław Szymanowski w „Tygodniku Ilustrowanym” zasługi Królikowskiego podnosił bardzo po-

25 Ibidem, s. 36.

26 List J. Chęcińskiego do S. Muchanowa z 13 VIII 1869, cyt. za: A. Wanicka, Dramat i komedia Teatrów Warszawskich 1868-1880, Kraków 2011, s. 314.

27 H. Modrzejewska, Wspomnienia i wrażenia, Kraków 1957, s. 199.

28 „Tygodnik Mód” 1871 nr 14, s. 4, https://crispa.uw.edu.pl/object/files/273609/display/Default [dostęp: 18 VIII 2020].

${ }^{29}$ „Kurier Warszawski” $1871 \mathrm{nr}$ 67, s. 11, https://jbc.bj.uj.edu.pl/dlibra/doccontent?id=721597 [dostęp: 18 VIII 2020].

30 „Kurier Codzienny” 1871 nr 67, s. 4, https://academica.edu.pl/reading/readSingle?page=4\&u$\mathrm{id}=40958564$ [dostęp: 10 XI 2020]. 
krętnie $^{31}$. Znacznie odważniejsze w krytyce były mniejsze pisma. „Kurier Świąteczny" żartował:

Ale bo też ten nasz Hamlet, to Hamlet prawdziwy, Hamlet, o jakim Szekspir marzył; a chociaż wygląda trochę przystaro, nie ma w tym nic dziwnego: przy takich zmartwieniach i przy takiej miłości! To jeszcze wiele, że biednemu Hamletowi włosy nie posiwiały ${ }^{32}$.

Najostrzej wypowiedział się Bogumił Aspis we własnym tygodniku „Opiekun Domowy", gdzie otwarcie odmówił aktorowi

nie tylko wszelkiej zasługi w oddaniu swojej roli, ale nawet wszelkiego prawa do porywania się na nią. [...] Królikowski z Hamleta zrobił coś zupełnie przeciwnego temu, czym jest według nas Hamlet i scharakteryzował go raczej na Don Kiszota w miejsce, jak trzeba, na mędrca i filozofa ${ }^{33}$.

Najwięcej zaufania budzą wypowiedzi trzech najbardziej doświadczonych i wnikliwych krytyków - Lubowskiego, Lewestama i Keniga, poparte analitycznymi uwagami na temat dramatu Shakespeare'a. Lubowski podkreślał, że rola Królikowskiego jest zbyt jednolita, podczas gdy ,istotę charakteru” Hamleta stanowią „najrozmaitsze i na pozór wprost kłócące się ze sobą znamiona”34. Jednostronność interpretacji Królikowskiego akcentował również Lewestam. Twierdził, że warszawski Hamlet to ,jedynie ów smętnie melancholijny marzyciel, nie zaś myśliciel, nie uszczypliwie dobroduszny filozof"35. Kenig pisał o roli Królikowskiego w podobnym tonie:

Przy całym więc niezmiernym wykończeniu, Hamlet skutkiem prawie tej nieustannej melancholiczno-rzewnej chmury, która się za nim wlekła jak jego długi czarny płaszcz, chwilami wyglądał jednotonnie, mdławo, a zwłaszcza chorowito, jako człowiek, od którego ani czynu spodziewać się, ani czynu żądać nikt nie ma prawa, i którego słabości trudno się dziwić36.

Opinie wyrażane prywatnie jeszcze mocniej przekonują o rozczarowaniu widzów. Ceniąca Królikowskiego Narcyza Żmichowska pisała w liście, że „rolę Hamleta od najobojętniejszego do najgwałtowniejszego słowa tak uroczyście pojął

31 W. Szymanowski, Przeglad teatralny. Hamlet, „Tygodnik Ilustrowany” $1871 \mathrm{nr}$ 170, s. 164, https://polona.pl/item/tygodnik-illustrowany-seria-2-t-7-nr-170-1-kwietnia-1871,Nzk5NDIyNA/11/\#item [dostęp: 18 VIII 2020].

32 „Kurier Świąteczny” 1871 nr 17, s. 3, https://crispa.uw.edu.pl/object/files/194277/display/Default [dostęp: 18 VIII 2020].

33 B. Aspis, Jeszcze o Hamlecie, „Opiekun Domowy” 1871 nr 38, s. 299, https://crispa.uw.edu.pl/ object/files/409485/display/Default [dostęp: 18 VIII 2020].

34 E. Lubowski, op. cit., s. 111.

35 F. H. L. [F. H. Lewestam], op. cit., nr 300, s. 204, https://polona.pl/item/klosy-czasopismo-illustrowane-tygodniowe-1871-t-12-nr-300-30-marca,OTI4ODEzODM/12/\#item [dostęp: 18 VIII 2020].

36 [J. Kenig], op. cit., nr 93, s. 1. 
i przedstawił, że wszystko się w jedno uniesienie skrzydeł zsumowało i miejsca prawdziwie tragiczne od tła nie odstały" ${ }^{\prime 37}$.

Po latach surowo oceniali rolę Hamleta w dorobku Królikowskiego Władysław Bogusławski („To nie człowiek, to abstrakcja”38) czy Wincenty Rapacki:

Niestety, i tu zawód. Nawet charakteryzacja, u artysty zwykle tak mistrzowsko obmyślana, tu zupełnie chybiła. Twarz bez zarostu i długie jasne włosy nadały jej, wbrew oczekiwaniu, wyraz starości i jakiegoś niedołęstwa. Za późno, za późno przyszedł Szekspir do artysty ${ }^{39}$ !

Współbrzmienie tak wielu różnych opinii prowadzi do wniosku, że występ Jana Królikowskiego jako Hamleta był nieudany.

\section{OFELIA LEPSZA OD SZEKSPIROWSKIEJ?}

Hamlet został wystawiony na benefis Modrzejewskiej, fetowano ją więc na premierze, jak nakazywał obyczaj:

Publiczność po skończeniu 4 aktu gromem oklasków i bukietów zasypała utalentowaną artystkę, [...] oprócz zaś tych bukietów doręczono jej w imieniu zwolenników sceny jeden olbrzymi wraz z drogocennym upominkiem, to jest bransoletą, na której wyryty napis zamykał wszystko, co chciano wyrazić, to jest: „Helenie Modrzejewskiej w uznaniu jej talentu i zasług dla sceny. Dnia 24 marca 1871 roku" ${ }^{\prime 4}$.

Kiedy po ostatniej przerwie premierowego wieczoru wiadomo było, że Ofelia już więcej nie pojawi się na scenie, część publiczności wyszła, robiąc sporo „tumultu”, co odnotował z niesmakiem „Tygodnik Mód”41.

Warszawscy krytycy prześcigali się w pochwałach. Lewestam pisał, że Modrzejewska:

nie tylko jako benefisantka, była królową wieczoru. [...] [Shakespeare] w kilku zaledwie głównych zarysach naszkicował kontur tej uroczej dziewczyny, której całą istotą jest słodycz, pokorna pod cudzą wolę uległość, ciche poddanie się, ale zarazem nieskończona siła miłości. [...] Ofelia pani Modrzejewskiej jest tryumfem dla niej od początku do końca, scena jej obłąkania nic nie ma wyższego w dziedzinie sztuki scenicznej ${ }^{42}$.

37 Cyt. za: J. Szczublewski, Wielki i smutny..., op. cit., s. 217.

38 W. Bogusławski, Sity i środki naszej sceny, Warszawa 1961, s. 127.

39 W. Rapacki, Sto lat sceny polskiej w Warszawie, Warszawa 1925, s. 115, http://www.encyklopediateatru.pl/ksiazka/708/sto-lat-sceny-polskiej-w-warszawie/strona/133 [dostęp: 10 XI 2020].

40 „Kurier Codzienny” $1871 \mathrm{nr} 67$, op. cit., s. 4.

41 „Tygodnik Mód” $1871 \mathrm{nr}$ 14, op. cit., s. 4.

42 F. H. L. [F. H. Lewestam], op. cit., nr 300, s. 204; nr 301, s. 219. 
Sceną obłąkania zachwycał się również Szymanowski³ ${ }^{43}$ Kenig zaś podkreślał, że w tym fragmencie aktorka ustrzegła się wszelkiej „,szpetności” czy „chorobliwości”, a wydobyła to, „co jest poezją, co wdziękiem, co pięknością" ${ }^{4}$.

Bardziej wstrzemięźliwy był Lubowski, który w obszernej recenzji poświęcił Modrzejewskiej tylko parę zdań. Stwierdził, że rola Ofelii jest co prawda „maleńka”, ale

może ją tylko grać niezwyczajna artystka. Najmniejsza przesada, najlżejsze zdradzenie nastroju lub fałszywa intonacja w głosie ośmieszy rolę, a co najmniej pozbawi jej poetyczności, najgłówniejszej cechy. Czy potrzeba dodać, że tego wszystkiego ustrzegła się pani Modrzejewska, umiejąc owładnąć czarem, jaki talentowi jej właściwy ${ }^{45}$ ?

Lakoniczna pochwała Lubowskiego znaczy jednak więcej niż inne, wyszła bowiem spod pióra autora powieści Aktorka uznawanej za paszkwil na benefisantkę ${ }^{46}$.

Do chóru chwalącego Ofelię Modrzejewskiej włączali się recenzenci wielu ga$z^{4}{ }^{47}$. Sprawozdawca „Kuriera Warszawskiego” był przekonany, że „Szekspir nie mógł piękniej w wyobraźni swej przedstawić sobie ten ideał dziewicy" ${ }^{48}$. Aspis twierdził, że „sam Szekspir nie odczuł i nie przeczuł Ofelii lepiej od tej artystki”"49. I tylko Aleksander Niewiarowski dostrzegł coś, czego nie zauważyli inni krytycy: „Pani Modrzejewska posiada wprawdzie w wysokim stopniu sztukę wyrażania uczucia, lecz samo uczucie stoi u niej na drugim planie; pierwszy zaś zajmuje wytworność i pełna wdzięku dystynkcja" ${ }^{50}$.

Dzisiaj można mieć wątpliwości, czy przesłodzona Ofelia Modrzejewskiej należała do jej wybitnych ról. Na pewno doskonale wpasowywała się w oczekiwania publiczności oraz ówczesny „,ideał dziewicy”51. Aktorka zagrała tak, by się podobać, a zarazem nie odejść zbyt daleko od wielbionego Shakespeare'a. Chyba zrealizowała dokładnie to, co zaplanowała: wzmocniła swoją pozycję w Warszawie, odniosła sukces i poszerzyła grono wielbicieli swojego talentu i urody.

43 W. Szymanowski, op. cit., s. 164.

44 [J. Kenig], op. cit., nr 93, s. 2.

45 E. Lubowski, op. cit., s. 111.

46 Pierwszy odcinek ukazał się 12 XI 1870 w warszawskim ,Tygodniku Romansów i Powieści”.

47 Zob. np.: „Tygodnik Mód” 1871 nr 14, op. cit., s. 3-4; „Kurier Codzienny” 1871 nr 67, op. cit., s. 4.

48 „Kurier Warszawski” 1871 nr 71, s. 1, https://jbc.bj.uj.edu.pl/dlibra/doccontent?id=721601 [dostęp: 18 VIII 2020].

49 B. Aspis, op. cit., s. 299.

50 [A. Niewiarowski], Kronika artystyczna, „Dziennik Warszawski” 1871 nr 95, s. 698, https:// crispa.uw.edu.pl/object/files/297374/display/Default [dostęp: 18 VIII 2020].

51 O Modrzejewskiej jako uosobieniu ideału aktorki swoich czasów pisał kilkakrotnie D. Kosiński, zob.: idem, Sztuka aktorska w polskim piśmiennictwie teatralnym XIX wieku. Główne problemy, Kraków 2003; idem, Dramaturgia praktyczna. Polska sztuka aktorska XIX wieku w piśmiennictwie teatralnym swej epoki, Kraków 2005; idem, Dlaczego Modrzejewska?, [w:] Helena Modrzejewska..., op. cit. 


\section{OSOBLIWY POLONIUSZ}

W roli Poloniusza obsadzony został Alojzy Gonzaga Żółkowski, jedna z największych gwiazd Teatrów Warszawskich od 1833. Trudno ustalić, kto namówił tego specjalistę od ról komediowych do zagrania Poloniusza, można jednak przypuszczać, że i tu zaważyła opinia Muchanowa. Być może prezes nie chciał, by zabrakło tak ważnego aktora w inscenizacji angażującej znaczną część zespołu.

O tym, że decyzje obsadowe zapadały na wysokich szczeblach władzy, świadczy korespondencja poprzedzająca zaproszenie Modrzejewskiej do Warszawy. Z listu Aleksandra Przezdzieckiego do aktorki z 24 lutego 1868 wynika, że jej krakowska Ofelia była jednym z impulsów tego zaproszenia:

Generał Hauke i b. sekretarz stanu Zaborowski zachwycili się nad zbiorem fotografii Rzewuskiego, a zwłaszcza nad Ofelią i oświadczyli, że bardzo pragnęliby zaprosić Panią na gościnne wystąpienia na scenie warszawskiej ${ }^{52}$.

Kilka dni później pisał:

O Hamleta zrobiliby starania, aby uzyskać pozwolenie, a trzeba by uprosić K rólikow skiego, aby wyuczył się roli Hamleta, Żółkowski byłby Poloniuszem. Mógłby być $\mathrm{z}$ tego świetny b e n e fi s ${ }^{53}$.

Obsada kluczowych ról była więc obmyślona znacznie wcześniej.

Żółkowski jako Poloniusz ostatecznie urzekł tylko jednego z recenzentów. Jedynie Lewestam chwalił „głębokie pojęcie roli w szczegółach i w spójnym ich zestawieniu - przesady ani cienia, tylko to, co niezbędne, co maluje w artystycznym wyciosaniu myśl poety niekiedy ledwie dotkniętą" ${ }^{54}$. Tymczasem Kenig uważał, że Żółkowski miał „mylne pojęcie roli” i przerysował wizerunek Poloniusza jako człowieka „dumnej i rycerskiej postawy”, wybierając „,nadętość dykcji, posuniętą nie tylko do deklamacyjności, ale prawie do skandowania, do cięcia mowy na wiersze" ${ }^{55}$. Szymanowski ${ }^{56}$ i Lubowski ${ }^{57}$ obeszli się z Żółkowskim nieco łagodniej, inni recenzenci przemilczeli jego rolę lub wykręcali się ogólnikami. I tylko „Kurier Świąteczny”58 pozwolił sobie na kpiny.

Tym większe znaczenie ma zajadła krytyka wygłoszona przez Modrzejewską nie publicznie, lecz prywatnie, we własnym salonie, w obecności niewielkiego grona przyjaciół. W prelekcji Aktor, którą zapisała później w Albumie, nie wymieniła nazwiska

52 Korespondencja Heleny Modrzejewskiej i Karola Chłapowskiego, op. cit., t. 1, s. 69-70.

53 Ibidem, s. 74.

54 F. H. L. [F. H. Lewestam], op. cit., nr 301, s. 220.

55 [J. Kenig], op. cit., nr 93, s. 2.

56 W. Szymanowski, op. cit., s. 164.

57 E. Lubowski, op. cit., s. 111.

58 „Kurier Świąteczny” 1871 nr 17, op. cit., s. 3. 
Żółkowskiego, ale krytykowała go z pasją za to, że zrobił z Poloniusza „poważnego ministra, człowieka z godnością, a nawet nieszczęśliwego”, co było nie tylko skrzywieniem „myśli autora”, ale też zdeformowało całość przedstawienia. „Nasz artysta nie zajmował się wcale całością sztuki ani resztą artystów, myślał tylko o sobie, chciał wirtuozować i chociaż mu udzielono rady, nie usłuchał"59.

Zdaniem Józefa Kotarbińskiego, oceniającego dorobek Żółkowskiego z większego dystansu, aktor w roli Poloniusza zamienił postać w

uroczyście deklamującego majordoma. Błąd ten był wynikiem braku literackiej kultury, której pewien stopień jest niezbędny, gdy aktor, choćby bardzo znakomity, odtwarza postacie z obcych arcydzieł i epok zamierzchłych ${ }^{60}$.

Kluczowe jest w tej opinii sformułowanie „literacka kultura”. Modrzejewska sięgała do Shakespeare'a, Żółkowski zaś do egzemplarza roli, czyli wersji Ostrowskiego. Jak słusznie zauważył Szczublewski, dziwaczny wizerunek Poloniusza był w znacznym stopniu zgodny z osobliwym przekładem Ostrowskiego. To właśnie thumacz ,przerobił Poloniusza na polskiego dygnitarza u duńskiego dworu, Żółkowski więc uznał, że nie może ośmieszać takiego Polaka"61. Komentując pretensje Modrzejewskiej, Dariusz Kosiński stwierdził:

Przestępstwo Żółkowskiego wydaje się oczywiste, ale jest tak tylko w kontekście przekonań interpretacyjnych podzielanych przez aktorkę - autorkę. Tymczasem przypomnieć trzeba, że Alojzy Żółkowski grał swojego ,polskiego wojewodę” nie dlatego, że takie miał widzimisię, ale dlatego, że taką postać znalazł w tekście, który mu wręczono. [...] Wygląda na to, że Żółkowski działał w zgodzie z tekstem i hołubioną przez Modrzejewską „,zasadą wierności”"62!

Modrzejewska chciała być wierna Shakespeare’owi, Żółkowski - egzemplarzowi teatralnemu. Te dwie postawy pokazują różnicę między literaturocentrycznym i teatrocentrycznym podejściem do tekstu i jego realizacji scenicznej.

\section{INNE SCENICZNE POMYŁKI}

Wątpliwości budziły także inne decyzje obsadowe. Jana Tatarkiewicza grającego Leartesa krytykowano za przesadę, krzykliwość i „zbytek tragiczności” (Lewestam ${ }^{63}$ ), za „sztuczną namiętność” (Lubowski ${ }^{64}$ ) i „,bezbarwność”

59 J. Szczublewski, Nieznany rękopis..., op. cit., s. 136, 137.

60 J. Kotarbiński, Aktorzy i aktorki, Warszawa 1925, s. 31, http://www.encyklopediateatru.pl/ksiazka/732/aktorzy-i-aktorki/strona/33 [dostęp: 10 XI 2020].

61 J. Szczublewski, Modrzejewska. Życie w odsłonach, Warszawa 2009, s. 127.

62 D. Kosiński, Sztuka aktorska..., op. cit., s. 158.

63 F. H. L. [F. H. Lewestam], op. cit., nr 301, s. 220.

64 E. Lubowski, op. cit., s. 111. 
$\left(\right.$ Niewiarowski $\left.{ }^{65}\right)$. Modrzejewska, domagająca się „całości i harmonii”, wręcz pomstowała na Tatarkiewicza w swoim Albumie:

Jak okropne np. czyni wrażenie trzpiot nie dający nikomu przyjść do słowa, przerywający w połowie frazesu drugiemu artyście, kręcący się bezustannie, przechodzący przez scenę, gdy go nie potrzeba, słowem: grający na swoją rękę, mówiący w ten sposób, że jego tylko słyszą, przez co wszystkie subtelności innych ról giną ${ }^{66}$.

Władysław Krogulski, wspominając po latach drogę artystyczną Tatarkiewicza, napisał dosadnie:

Shakespeare, tragedia, Modrzejewska, benefis tak silnie działały na wrzący jego umysł, iż o całe niebo przeholował miarę, czyli że w najwyższym stopniu był nienaturalnym. $\mathrm{Z}$ jakiego on stanowiska wychodził? Nie wiem, ale wiem, iż zatarł zupełnie człowieka, co u Shakespeare’a jest zbrodnią, a dał nam jakiegoś dziwoląga wściekłego ciągle i ciągle krzyczącego wniebogłosy, słowem, grzeszył zbytkiem tragiczności ${ }^{67}$.

Ciekawym przypadkiem była też rola Króla w wykonaniu Alojzego Stolpego. Jak wiadomo, właśnie scena zabójstwa panującego władcy budziła niepokój cenzorów. Być może dlatego postanowiono (Stolpe? Chęciński? Muchanow?) ocieplić wizerunek króla. „Tygodnik Ilustrowany” uznał, że Stolpe oddał rolę Klaudiusza „dobrze” ${ }^{68}$. Lubowski w „Bluszczu” podkreślił jednak z niesmakiem, że „nikczemnego zbrodniarza, kłamcę i czarnego intryganta zrobił p. Stolpe prostodusznym, a w scenie modlitwy żałującym zbyt podniośle win swoich" ${ }^{69}$. Najszerzej wypowiedział się Lewestam:

Powaga postawy, chód majestatycznie kroczący, słowa rzucane jakby odgłosy bliskiego grzmotu, w krótkich, lecz gwałtownych abcugach - wszystko to dawało nam obraz nieco nadęty, lecz nie przedstawiało tyrana duńskiego, przebiegłego zbrodniarza [...] z wyjątkiem kilku morderstw, których się w swym życiu dopuścił, jest to król wielce przyjemny i miły, łatwy w pożyciu i wcale nie dumny. Napuszoność Klaudiusza na scenie psuje ten efekt dobroduszności w przestępcy na tronie ${ }^{70}$.

W „Kurierze Świątecznym” w artykule stylizowanym na głos poczciwego prostaka napisano:

Takiego niedobrego człowieka, jak Klaudiusz król duński, to już chyba nie ma drugiego na świecie; żona jego, którą niby kochał, połyka w ostatniej scenie truciznę przez niego sporzą-

65 [A. Niewiarowski], op. cit., s. 698.

66 J. Szczublewski, Nieznany rękopis..., op. cit., s. 134.

67 W. Krogulski, Notatki starego aktora. Przewodnik po teatrze warszawskim XIX wieku, wybór i oprac. D. Jarząbek-Wasyl, A. Wanicka, Kraków 2015, s. 613.

68 W. Szymanowski, op. cit., s. 164.

69 E. Lubowski, op. cit., s. 111.

70 F. H. L. [F. H. Lewestam], op. cit., nr 301, s. 220. 
dzoną i przeznaczoną dla Hamleta, a on nic, ani go to ziębi, ani parzy, żeby choć nosem skrzywił, i to nie. Czyż warto było zabijać pierwszego męża Gertrudy, ażeby później tak obojętnie przyglądać się jej śmierci ${ }^{71}$.

Ironiczny ton tej recenzji wydaje się celniejszym narzędziem krytyki niż słowa Lewestama, zapominającego jakby o istnieniu cenzury. Postulowane przez niego wyjaskrawianie zbrodni „,przestępcy na tronie” mogło się skończyć zakazem wystawiania sztuki. Być może dlatego Stolpe dodał Królowi powagi i patosu, a recenzenci woleli nie komentować postaci złego władcy, który sięgnął po koronę na drodze zbrodni.

Lewestam w podobny sposób potraktował rolę królowej Gertrudy w wykonaniu Walerii Niewiarowskiej. Przyjrzał się jej wnikliwie, ale jakby w oderwaniu od politycznych okoliczności:

Ta wielce pożyteczna zawsze artystka na ten raz zasklepiła się do zbytku w nieruchomej powadze królowej; mimika twarzy nie towarzyszyła prawie nigdy jej słowom; była to maska, bardzo nęcąca (chętnie to wyznajemy), ale w tej masce życia ni śladu ${ }^{72}$.

Lubowski starał się docenić w tej kreacji ,pewne studia, które zasługują na uznanie" 73 , w podobnym duchu napomknął o niej recenzent „Kuriera Warszawskiego"74, Szymanowski zaś skwitował wysiłki aktorki jednym zdaniem: „Marmurową twarz i królewską powagę wiarołomnej Gertrudy umiejętnie uplastyczniła pani Niewiarowska”75. Kpiarski ton przybrał znów „Kurier Świąteczny”, czyniąc nieelegancki przytyk do tuszy aktorki:

Warto by dla królowej, matki Hamleta, dobierać trochę silniejsze damy honorowe, bo te co dziś są, uginają się widocznie pod ciężarem umierającej królowej. Cóż by to było, jeśli by ją broń Boże upuściły na ziemię ${ }^{76}$.

Być może Niewiarowska po prostu źle pojęła swoją rolę, ale nie można wykluczyć, że próby hieratyzowania postaci Królowej miały chronić przedstawienie przed krytyką cenzorów, szczególnie podejrzliwie przyglądających się scenicznym wizerunkom władców.

Najbardziej bodaj kuriozalną postać stworzył Józef Grzywiński występujący w roli Ducha. Kenig pisał:

Nie naszą rzeczą jest wskazywać, jakich środków charakterystyki zewnętrznej należało użyć, by nadać owemu duchowi pozór nadprzyrodzonego widziadła [...] To wszakże powiedzieć mu-

71 „Kurier Świąteczny” 1871 nr 17, op. cit., s. 3.

72 F. H. L. [F. H. Lewestam], op. cit., nr 301, s. 220.

73 E. Lubowski, op. cit., s. 111.

74 „Kurier Warszawski” $1871 \mathrm{nr}$ 67, op. cit., s. 11.

75 W. Szymanowski, op. cit., s. 164.

76 „Kurier Świąteczny” 1871 nr 17, op. cit., s. 3. 
simy, że tak jak go widzieliśmy, robił tylko wrażenie bardzo zdrowego i silnego mężczyzny, nie mającego wcale pozoru, że przestał żyć bardzo ziemskim i pożywnym życiem. [...] Mowa [ducha] nadto była rzewna, nadto po ludzku zmienna. Nam by się zdawało, że duch i tu powinien zapomnieć o ziemi, uwydatnić to w dykcji przyciszonej, jednotonnej, niby tchnieniu nie mowie ${ }^{77}$.

„Kurier Świąteczny” jak zwykle ironizował:

Duch ojca, ukazując się po raz pierwszy Hamletowi, ma postać wcale niezagrobową; to panie, szlachcic jak Herkules, muskuły ma co się nazywa, a nawet nie brak mu rumieńców. Co mi to za duch, kiedy znać po nim, że jadł śniadanie i obiad, i że kolacją także nie pogardzi ${ }^{78}$.

Za ten błąd obsadowy winić trzeba chyba reżysera, chociaż - może i w tym był jakiś zamysł? Teatr dziewiętnastowieczny miał przecież sposoby na pokazywanie eteryczności i ulotności duchów. Tymczasem Chęciński zjawę zastąpił postawnym młodym trzydziestojednoletnim mężczyzną, o znacznym wzroście i tuszy oraz basowym głosie. Grzywiński był doskonały w rolach szlagonów, a nie bladych widm. Czyżby zatem chodziło o uwypuklenie rycerskiej postury w kontraście z niskim i drobnym Hamletem? O miraż bohaterskich przodków, których Polacy powinni pomścić? Trudno zgadnąć. Rzecz jasna, o takich skojarzeniach nie mogło paść ani słowo w recenzjach.

Role Rosenkrantza (Władysław Szymanowski), Gildensterna (Feliks Schober) i Horacego (Władysław Piasecki) wypadły blado. Recenzenci nie zwrócili na nie uwagi, jedynie Lubowski napominał aktorów, ,ażeby nie traktowali tak lekkomyślnie ról swoich niewielkich" "79. Ciekawsi okazali się odtwórcy dwóch Grabarzy - Michał Chomiński i Józef Damse. „Kurier Warszawski” i „Tygodnik Ilustrowany” chwaliły staranność wykonania ról ${ }^{80}$, a „Tygodnik Mód” pisał ciepło, że aktorzy: „oddali je jednak z taką prawdą i artyzmem, że im jak najsłuszniej należy się szczery poklask podzięki" ${ }^{81}$. Lewestam chwalił scenę cmentarną za „wystudiowany wybornie humor Szekspirowskich postaci ludowych" ${ }^{\circ 2}$. Natomiast Krogulski w Notatkach starego aktora wspominał:

Chomiński i Damse zupełny kontrast ze sobą tworzyli, o ile pierwszy pozował ciągle na poważnego, o tyle drugi był pustakiem całe swoje życie. [...] Na przykład w Hamlecie [Damse] grał grabarza drugiego, pierwszym był Chomiński. Ponieważ ten drugi grabarz nic nie ma w swej

77 [J. Kenig], op. cit., nr 92, s. 2, https://crispa.uw.edu.pl/object/files/335097/display/Default [dostęp: 18 VIII 2020].

78 „Kurier Świąteczny” 1871 nr 17, op. cit., s. 3.

79 E. Lubowski, op. cit., s. 111.

${ }^{80}$ „Kurier Warszawski” 1871 nr 67, op. cit., s. 11; W. Szymanowski, op. cit., s. 164.

81 „Tygodnik Mód” $1871 \mathrm{nr} 14$, op. cit., s. 4.

82 F. H. L. [F. H. Lewestam], op. cit., nr 301, s. 220. 
roli do odznaczenia się, a Damse koniecznie chciał zwrócić uwagę publiczności, uderzył więc w strunę charakteryzacji - zrobił małpią maskę i poprzyklejał sobie z tektury wyrobione uszy mające długości przynajmniej po ćwierci łokcia. Celu dopiął - uwagę na siebie zwrócił, ale jednocześnie ośmieszył scenę grobową, a raczej cmentarną, naraził się na wielkie oburzenie i Chomińskiego, i reżyserii, na koniec na monitum dyrekcji ${ }^{83}$.

Nie wiadomo, podczas którego przedstawienia Damse dopuścił się opisanego wybryku, ale na pewno nie na premierze, bo pozostałby jakiś ślad w omówieniach prasowych.

\section{REŻYSER}

Publiczność dziewiętnastowieczna ceniła, a nawet wielbiła aktorów. Mogła dużo wybaczyć, o ile aktor na scenie przyciągał uwagę i poruszał emocje. W realizacji Hamleta wystąpił liczny zespół (dziewiętnaście aktorek i aktorów wymienionych z nazwiska) oraz sześćdziesięcioro czworo statystów, w tym kilka osób z baletu, a nawet czterech policjantów zatrudnionych do niesienia trumny. Za koncepcję głównych ról odpowiadali, rzecz jasna, przede wszystkim aktorzy. Interpretacyjno-intelektualny wkład reżysera w całość inscenizacji był istotny głównie na etapie wyboru dzieła, opracowania egzemplarza i rozdania ról. Potem pozostawały mu już zadania organizacyjno-techniczne: czuwanie nad przebiegiem prób, angażowanie statystów, układanie grup na scenie, sterowanie wejściami i wyjściami, decyzje scenograficzne. Miał również pewien wpływ na kostiumy, tym większy, im mniejsza rola, ponieważ gwiazdy o swoich kostiumach decydowały same i same też je finansowały.

Jaką rolę w przypadku Hamleta 1871 odegrał Chęciński? Na pewno przyczynił się do wystawienia arcydramatu w Warszawie, obok Heleny Modrzejewskiej, konsekwentnie wprowadzającej Shakespeare'a do warszawskiego repertuaru, oraz Marii Kalergis, która wpłynęła na męża, Sergieja Muchanowa ${ }^{84}$. Chęciński zabiegał nie tylko o Shakespeare’a, ale także o Słowackiego czy Schillera, był oczytany, inteligentny i pracowity. Z dzisiejszej perspektywy wydaje się, że był znacznie lepszym reżyserem i artystą, niż został zapamiętany i zapisany w historii teatru. Krogulski napisał po latach: „Scenariusze jego Hamleta i Otella uchodzą za wzór doskonałości prac w tym rodzaju" ${ }^{85}$, wspominał również o Hamlecie jako „tragedii świetnie przez Chęcińskiego wyreżyserowanej i wystawionej"86.

83 W. Krogulski, op. cit., s. 492.

84 Zdaniem Szczublewskiego: „Prezesowa wmówiła szefowi cenzury, że zabójstwo króla jest w tej sztuce wyłącznie wewnętrzną sprawą owej tam jakiejś niepoważnej rodziny królewskiej, więc nie «zatrąca polityką»", idem, Modrzejewska..., op. cit., s. 126.

85 W. Krogulski, op. cit., s. 580.

86 Ibidem, s. 613. 
Współczesna badaczka konstatuje, że Chęciński ,jako jeden z pierwszych zwracał uwagę na konieczność gry zespołowej i spójną budowę koncepcji inscenizowanej sztuki" ${ }^{87}$. Wprawdzie od ponad trzydziestu lat czynił to samo Jan Tomasz Seweryn Jasiński, niemniej ocena starań Chęcińskiego wydaje się słuszna.

Egzemplarz reżyserski Hamleta to wydana we Lwowie książka. Na jej tekturowej oprawie widnieje odręczny napis Chęcińskiego: „Scenariusz - Hamlet”. Na początku doklejono dziesięć kart (jedną wydarto, zostało więc dziewięć), po części pustych, po części zapełnionych odręcznymi notatkami i rysunkami reżysera. Doklejka i wszystkie określenia poczynione czarnym ołówkiem są z pewnością autorstwa Chęcińskiego. Co do pozostałych nie ma pewności, a zrobiono je na różne sposoby: czarnym atramentem oraz kredkami - niebieską, czerwoną i zieloną. Na trzech pierwszych stronach doklejki wypisano nazwiska członków Chóru, na następnych pięciu kartach Chęciński nakreślił szkice sytuacyjne „obrazów" $"$. Podobne rysunki, mniejsze, lecz niekiedy dokładniejsze i opatrzone odręcznymi notatkami uzupełniającymi drukowane didaskalia, rozsiane są po egzemplarzu.

Chociaż krytycy dziewiętnastowieczni rzadko zwracali uwagę na pracę reżysera, tym razem pojawiło się kilka uwag. Szymanowski reżyserię komplementował: „Układ sceniczny i sumienne dopilnowanie wszystkich szczegółów nie pozostawiają nic do życzenia"89. Kenig wyłapał pewne niedorzeczności w pierwszej, usuniętej później, scenie:

w pierwszej scenie trzech ludzi znajduje się na tarasie zamku; ,zimno jest przenikliwe”, północ, ludzie czekają na nadprzyrodzone zjawisko, na ukazanie się ducha, a przed zjawiskiem równie jak po nim rozmawiają tak głośno, tak swobodnie, jakby się znajdowali w dobrze ogrzanej izbie i czekali nie na ducha, ale na gospodarza mającego im przynieść wieczerzę. Ludzie w tym położeniu rozmawiać by powinni cicho, tajemniczo, z pewną trwogą nawet; tego zdaje się wymagać najprzód prawda, następnie efekt dramatyczny ${ }^{90}$.

Po chwili jednak dodał: „Zatrzymujemy się jednak, wiedząc ile trudności mogło kosztować przedstawienie Hamleta nawet takie, jakie jest na naszej scenie" ${ }^{\text {"91. }}$ Istotną pochwałę wyraził „Kurier Warszawski”: „Nie ma rażących ustępów, wszystko zlewa się z sobą harmonijnie, przynosząc zaszczyt scenie naszej i jej pracownikom. Część wielka tej zasługi spada i na reżyserię"92.

87 M. Kuraś, Jan Chęciński, „Pamiętnik Teatralny” 2011 z. 1-2, s. 116.

88 Rysunki, dopiski oraz próbę rekonstrukcji przedstawienia zob. J. Szczublewski, Warszawski scenariusz..., op. cit.

89 W. Szymanowski, op. cit., s. 164.

90 [J. Kenig], op. cit., nr 92, s. 2.

91 Ibidem.

92 „Kurier Warszawski” 1871 nr 67, op. cit., s. 11. 


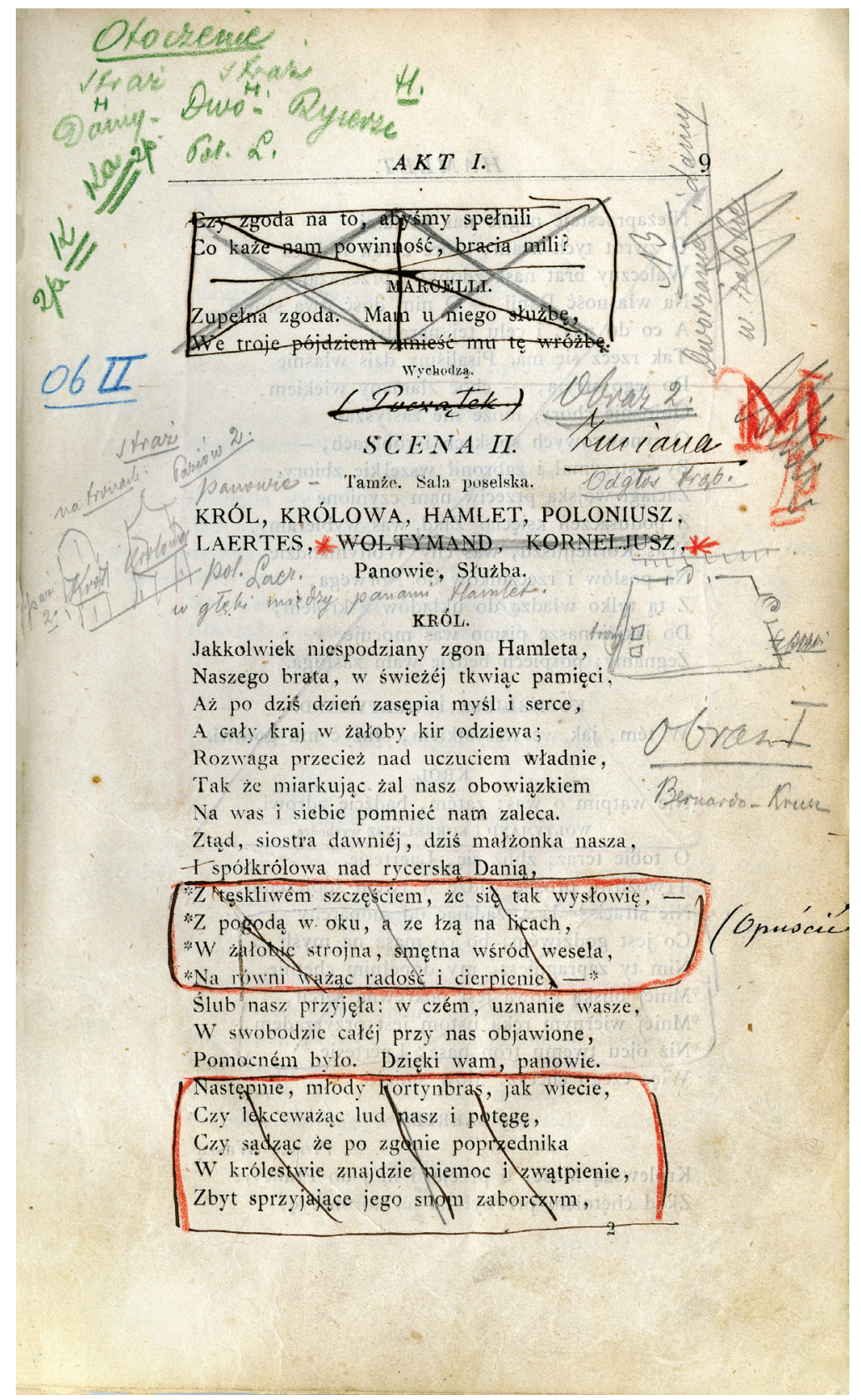

Hamlet, strona z egzemplarza reżyserskiego Jana Chęcińskiego, Zbiory Specjalne Instytutu Sztuki PAN. Fot. Krzysztof Piłat 
Reżysera zabolały sugestie, że nie był samodzielny i posiłkował się sprowadzonym z Anglii scenariuszem oraz wzorami kostiumów. Opublikował w tej sprawie list w „Kurierze Codziennym”:

oświadczam jasno i głośno, że tylko skróceń tragedii Hamlet dokonałem podług angielskiego wydania, skróconego przez komitet współziomków nieśmiertelnego autora; że zresztą dyrekcja teatrów do wystawienia Hamleta nic nie potrzebowała sprowadzać z zagranicy; że układ scen czyli scenariusz (mise en scene) i zastosowanie dekoracji do tej tragedii, tak samo jak scenariusze wszystkich dzieł dramatycznych wystawianych w czasie mojej reżyserii, zostały dokonane przeze mnie podług mojego własnego pomysłuํ.

Mając w pamięci rozbieżne koncepcje ról realizowane przez aktorów, należałoby oddać sprawiedliwość Chęcińskiemu, jeśli bowiem całość wypadła nie najgorzej, to głównie dzięki jego staraniom. Zachowany egzemplarz potwierdza jego pracę nad koncepcją całości i realizacją poszczególnych scen. Widzowie zawdzięczali mu także usunięcie najbardziej rażących dziwactw przekładu Ostrowskiego.

Po części od reżysera, a po części od możliwości finansowych teatru zależała „wystawa” przedstawienia. Analiza wszystkich wzmianek o scenografii i kostiumach w Hamlecie 1871 skłania do opinii, że pod tym względem było mizernie $^{94}$. Chęciński pisał do Muchanowa, że Hamleta (i inne tytuły) wystawi bez nowych dekoracji, jedynie z dodatkiem „niewielkich akcesoriów do dekoracji dawniejszych"95. Kostiumy - jak zwykle w przypadku Dramatu - szyto w przerwach zawsze ważniejszych planów Opery i Baletu. Krytycy nie poświęcili scenografii ani słowa, co oznacza, że nie przykuwała uwagi - zapewne była mało efektowna, ale też nie budziła kontrowersji, choć zauważono, że niektóre elementy dekoracji wzięto z przedstawień operowych Żydówki i Makbeta. Efekt okazałości królewskiego dworu Chęciński budował, wprowadzając na scenę statystów, co świadczy o jego reżyserskiej sprawności.

O kostiumach i rekwizytach wiemy niewiele. Były pancerze, kolczugi i hełmy, Horacy i Hamlet nosili miecze, a szaty Króla i Królowej miały treny podtrzymywane przez paziów. W „Kurierze Warszawskim” odnotowano, że Królikowski „W scenie cmentarnej postawą przypominał słynny obraz Eugeniusza Delacroix: czarne pióro na birecie, czarny płaszcz pomięty, czarna szpada, postać wiotka,

93 „Kurier Codzienny” $1871 \mathrm{nr} 68$, s. 6, https://academica.edu.pl/reading/readSingle?page=6\&uid $=40958565$ [dostęp: 10 XI 2020].

94 Zob. H. Waszkiel, op. cit.

95 J. Szczublewski, Wielki $i$ smutny teatr..., op. cit., s. 67. Zaginęło tak wiele materiałów źródłowych, że cały nasz ogląd teatru XIX w. stoi na glinianych nogach. Tym bardziej warto byłoby opracować wszystko, co się zachowało, np. opublikować zbiory recenzji teatralnych najważniejszych krytyków z tamtych lat. 
nachylona, wzrok gorączkowy"96. Lewestam krytykował ciężki płaszcz Hamleta i postarzającą go charakteryzację ${ }^{97}$, Rapacki zaś wspominał jego „twarz bez zarostu i długie jasne włosy"98. Wygląd Ofelii w scenie obłąkania znamy z fotografii Mieczkowskiego ${ }^{99}$ : jasne, rozpuszczone włosy sięgające pasa, jasna lekka suknia odkrywająca ramiona, wianek na głowie oraz kwiaty we włosach i przy sukni. W tej kwestii Chęciński z pewnością nie miał nic do powiedzenia.

Ówczesna publiczność przyzwyczajona była do operowego rozmachu w Teatrze Wielkim, bo imponujące inscenizacje w stylu teatru romantycznego pojawiały się w Warszawie już od ponad czterdziestu lat, poczynając od słynnego Chtopa milionowego w 1829, z fascynującą scenografią Antonia Sacchettiego. $\mathrm{Na}$ tle imponujących dekoracji Sachettiego, który współpracował z Teatrami Warszawskimi jako główny dekorator aż do 1868, scenografia Hamleta wyglądała skromnie, łatana elementami wyciągniętymi z magazynów. Współcześnie Andrzej Żurowski, dopatrzył się „,widowiskowości” i „postromantycznej nastrojowości" w scenicznej koncepcji Hamleta ${ }^{100}$, ale taki wniosek wydaje się przesadny. Nastrojowość i niesamowitość scen z Duchem została przecież popsuta przez krwistość Grzywińskiego, Grabarze próbowali wygłupów, a hieratyczność upozowanych monarchów bliższa była koturnowej stylistyce klasycystycznej niż emocjom romantyzmu. Gdy w poprzednich dziesięcioleciach zachwycał mistrz Sacchetti, prasa trzęsła się od pochwał i opisów. Całkowite milczenie komentatorów na temat wystawy Hamleta oznacza tylko, że obyło się bez wstydu i skandalu.

Muzyka do spektaklu także nie sprawiła większego wrażenia, choć skomponował ją dyrektor zespołu Opery, Stanisław Moniuszko. Jak zwykle w przedstawieniach zespołu Dramatu, muzyka była głównie „użyteczna”. Towarzyszyła konkretnym momentom przedstawienia (wejście króla, organy w scenie na cmentarzu), uzupełniana o oczywiste efekty dźwiękowe, jak zegar bijący dwunastą w scenie z Duchem czy głos trąb i salwa armatnia za sceną podczas końcowego pojedynku. Zapamiętano tylko Piosnkę obłakanej Ofelii zaczynającą się od słów „Któż mi powie, cni drużbowie, gdzie kochanek mój?”, którą Moniuszko opublikował osobno na głos i fortepian ${ }^{101}$, a następnie włączył do Śpiewnika domowego.

96 „Kurier Warszawski” 1871 nr 67, op. cit., s. 11.

97 F. H. L. [F. H. Lewestam], op. cit., nr 300, s. 204.

98 W. Rapacki, op. cit., s. 115.

99 Zob. przypis 8.

100 A. Żurowski, Szekspir w cieniu gwiazd, Gdańsk 2001, s. 200.

101 „Piosnka obłąkanej Ofelii” nucona przez Panią Modrzejewska w tragedii Hamlet. Muzyka S. Moniuszki, Warszawa [1871]. 


\section{WYBITNE PRZEDSTAWIENIE?}

Zainteresowanie warszawiaków premierą Hamleta było ogromne, a uzmysławiają to liczby. W ciągu pierwszych siedmiu tygodni zagrano Hamleta dziesięć razy $(24,30 \mathrm{III}, 1,12,21,26,28 \mathrm{IV}, 3,5,10 \mathrm{~V})$, co stanowiło duży sukces. Przedstawienie obejrzało w tym okresie dziesięć tysięcy dwieście sześćdziesiąt osób ${ }^{102}$. Łącznie w 1871 odbyło się siedemnaście spektakli, w 1872 - siedem, w 1873 - trzy, w 1874 - cztery. W sumie Hamlet w reżyserii Chęcińskiego miał trzydzieści jeden przedstawień ( $\mathrm{w}$ tym cztery $-\mathrm{w}$ Teatrze Letnim, pozostałe $-\mathrm{w}$ Teatrze Wielkim) $)^{103}$.

Dane statystyczne wskazują na to, że spektakl przyjęto dość dobrze, choć recenzenci mieli tyle zastrzeżeń. Dziś zdumiewa aż tak silna obecność tej premiery w historii polskiego teatru, niewspółmierna - jak się wydaje - do jej rangi artystycznej. Wystawiono przecież wyjątkowo zły przekład, aktorzy grali każdy sobie, takie gwiazdy jak Królikowski i Żółkowski poniosły klęskę, a Modrzejewska jako Ofelia urzekała raczej wdziękiem i urodą niż interpretacją. Przedstawienie chwilami śmieszyło w sposób niezamierzony, a wystawa nie mogła się nawet równać z pysznymi inscenizacjami oper i melodram pokazywanych na tej samej scenie.

Ale może to nieprawda? Czy potrafimy krytycznie czytać prasowe recenzje z epoki i wyłapywać ukryte informacje, skoro publikacje z jednej strony ograniczała cenzura, a z drugiej - profil czasopisma? Nie bez znaczenia były też osobowości autorów. Łatwo tu o manipulacje, jak w przypadku oceny chłodnych wypowiedzi Keniga na temat Modrzejewskiej w roli Ofelii. Szczublewski tłumaczył ten chłód prywatnymi względami: „Kenig był mężem zdetronizowanej i usuniętej przez Modrzejewską w cień pierwszej artystki warszawskiego dramatu, Salomei Palińskiej" "104. Niewykluczone jednak, że rola ta rzeczywiście nie była tak udana jak inne (także szekspirowskie) w repertuarze wielkiej aktorki.

„Filozoficzna zaduma” Królikowskiego nie spodobała się współczesnym, ale może jego interpretacja tylko rozminęła się z upodobaniami widzów, którzy nie lubili chłodnej gry? Monografista Królikowskiego, Witold Filler, sugerował, że „mniej bolesnych westchnień, a więcej myślowych point” niekoniecznie trafiało

102 J. Szczublewski, Warszawski scenariusz..., op. cit., s. 131. Na widowni Teatru Wielkiego, liczącej 1085 miejsc, zasiadło w kolejne wieczory 1085, 1064, 1071, 1085, 1085, 1065, 1065, 929, 851, 960 osób.

103 Zestawienie wg: H. Secomska, Repertuar teatrów warszawskich 1863-1890, Warszawa 1971. A. Wanicka ustaliła, że w latach 1868-1880 w Teatrach Warszawskich: „,wprowadzono do repertuaru 9 sztuk angielskiego dramaturga, ale za to były one obecne niemal stale w repertuarze, wystawiane często kilkanaście razy w sezonie, łącznie 203 razy”, a ta statystyka pokazuje, że Shakespeare „w latach 1868-1880 był trzecim - po Sardou i Feuilletcie - najczęściej oglądanym autorem”, eadem, op. cit., s. 125 i 128.

104 J. Szczublewski, Nieznany rękopis..., op. cit., s. 142. 
w gusta ówczesnej publiczności ${ }^{105}$. Czy to trafna sugestia? Publiczność to twór wieloosobowy i nie zawsze opinie zapisane czy opublikowane zgadzały się z odczuciami niewyrażonymi na piśmie. Z pewnością inaczej odbierali Hamleta widzowie znający dzieło Shakespeare'a z lektury lub też innych wystawień (w Krakowie, Lwowie, za granicą), a inaczej publiczność mniej wykształcona i mniej bywała.

Jaki był wpływ fizyczności aktora na odbiór jego roli? Modrzejewska tak czarowała urodą i wdziękiem, że zapewne niektórym widzom było obojętne, o czym mówi i kogo gra - wystarczał im jej widok. Królikowski z kolei, chociaż stawiano go za wzór aktora, który uporczywą pracą pokonał ograniczenia fizyczne (niski wzrost, drobna postać), nie zdołał, jak zauważył Kosiński, „,całkowicie przełamać bariery zewnętrzności i nigdy właściwie nie podejmował ról należących do właściwego «wydziału» bohaterów dramatycznych"106. Żurowski w książce o Modrzejewskiej posuwa się do złośliwości o jej partnerze:

podstarzały gwiazdor w blond peruce, dźwigający ciężki czarny płaszcz, a przy tym... najniższy wzrostem pośród protagonistów, jako duński książę musiał zaiste prezentować się nieco żałośnie. Ni perfekcyjna technika aktorska, ni kontredanse krytyków wobec mistrza nie starczyły, by Królikowski mógł Hamleta, którego ujął jako monotonnego, smutnego melancholika i marzyciela, wpisać pomiędzy swe role rzeczywiście wybitne ${ }^{107}$.

To sąd jawnie niesprawiedliwy. Peruka i płaszcz nie deprecjonowały roli, wiek aktora również nie miał aż takiego znaczenia, a „kontredanse krytyków” potwierdzają tylko, że za mało wiemy, byśmy mogli oceniać, co było „wybitne”, a co nie.

Czy anielski wdzięk Ofelii, odbieranej jako „lechicka dziewica, czysta i niepokalana" ${ }^{108}$, to sukces aktorki czy porażka? Nawet Szczublewski musiał zauważyć, że

Sepiowy cień tej Modrzejewskiej zachowa się w ładnych pracach nadwornego jej w Warszawie fotografa, Mieczkowskiego. Ofelia jest jakoś ła dn i e j obłąkana niż tamta szalona z Krakowa $^{109}$.

Z jakich pozycji mamy patrzeć na tę rolę - urzeczonych widzów, zafascynowanych badaczy czy może współczesnych studiów nad Ofelią? Może warszawski Hamlet 1871 przeszedł do historii głównie dzięki Modrzejewskiej, ale wcale nie ze względu na tę konkretną rolę Ofelii, lecz ze względu na jej późniejszą wielką karierę?

105 W. Filler, Jan Królikowski, Warszawa 1959, s. 74-75.

106 D. Kosiński, Dramaturgia praktyczna..., op. cit., s. 23.

107 A. Żurowski, MODrzeJEwSKA ShakespeareStar, Gdańsk 2010, s. 44.

108 „Kurier Codzienny” $1871 \mathrm{nr} 67$, op. cit., s. 4.

109 J. Szczublewski, Modrzejewska..., op. cit., s. 126. 
Postawmy jeszcze jedno pytanie: na ile nasze dzisiejsze praktyki teatralne rzutują na postrzeganie dawnych spektakli? Powróćmy do przekładu Ostrowskiego. Nadal nie wiemy, dlaczego wybrano właśnie to thumaczenie. Szczublewski nazwał je „cudacznym”"110, a Tymon Terlecki „najcudaczniejszym w świecie" 111 . Najbardziej krytyczni byli ci komentatorzy (poczynając od Modrzejewskiej), którzy znali oryginał. Pomijając jednak dziwaczność polonizacyjnych pomysłów Ostrowskiego, trzeba zaznaczyć, że swobodne adaptacje klasyki zyskały w naszych czasach nie tylko prawo obywatelstwa, ale są traktowane jako dowód swobody artystycznej teatru uwolnionego spod jarzma literatury. Ciekawym przyczynkiem do sprawy jest uwaga poczyniona przez Wandę Świątkowską, która pisząc o przekładzie Hamleta dokonanym przez Osterwę w 1940, zauważa: „W kontekście historii adaptacji można by powiedzieć, że jeśli Bogusławski i Kamiński to teza, a Ostrowski - antyteza, to Osterwa stanowi połączenie obu tradycji" "112. Jeśli wspomnimy klasycystyczne przeróbki Jean-François Ducisa dopisującego do tragedii Shakespeare'a szczęśliwe zakończenia, to widać, jak historia zatacza koło: od swobodnych adaptacji dramatów literackich na potrzeby konkretnych scen i widzów, przez próby dochowania wierności autorowi, po współczesną pełną swobodę w traktowaniu literackiej podstawy dzieła teatralnego.

Powtórzmy: nurt nowego historycyzmu przekonuje, że do „obiektywnej” historii nie mamy dostępu - jest tylko narracja badacza, uzależniona od miejsca obserwacji, dostępnych lub wybranych narzędzi badawczych, świadomości, wiedzy ogólnej, poglądów i predyspozycji. W przypadku historii teatru sprawa jest szczególnie skomplikowana, ponieważ wielotworzywowy charakter sztuki teatru lokuje ją na przecięciu literatury, aktorstwa, plastyki, muzyki itd. Choć od Wielkiej Reformy Teatru dzieli nas ponad wiek, często dominującą narracją pozostaje perspektywa literaturocentryczna. To drugi, obok aury otaczającej Helenę Modrzejewską, czynnik zapewniający Hamletowi z 1871 tyle uwagi w historii polskiego teatru. Nie o wydarzenie teatralne chodziło, lecz o sztukę Shakespeare'a.

Pociąga to za sobą dalekosiężne konsekwencje. Literaturocentryczne podejście do badań teatralnych przyczyniło się do utrwalenia krytycznej oceny lat międzypowstaniowych XIX wieku w dziejach teatru polskiego, opartej na przekonaniu, że skoro nie grywano wówczas ,wielkiego repertuaru”, to teatr był niewiele wart. Za ,wielki repertuar” historycy uznali klasykę w rodzaju tragedii starożytnej, Shakespeare'a, Schillera, Racine'a, Corneille'a, pogardliwie odnosili

\footnotetext{
110 Ibidem, s. 125

111 T. Terlecki, Pani Helena. Opowieść biograficzna o Modrzejewskiej, Londyn 1962, s. 91.

112 W. Świątkowska, Książę Hamlet Juliusza Osterwy, Kraków 2009, s. 63.
} 
się natomiast do dopuszczanych przez cenzurę $\mathrm{i}$ wystawianych w latach 1831-1868 dram i komedii takich autorów, jak Kotzebue, Pixérécourt, Scribe, Dumas, Bayard, Desnoyer, Ducange, Dumanoir, Augier, Sandeau, Labiche, Lausanne, Mélesville, Nestroy czy Théaulon de Lambert. Podobnie podchodzono do polskiego repertuaru: skoro na scenach nie można było oglądać dzieł Mickiewicza, Słowackiego i Krasińskiego, to nie warto zawracać sobie głowy wystawianymi sztukami Dmuszewskiego, Skarbka, Stanisława Bogusławskiego, Jasińskiego, Korzeniowskiego, Chęcińskiego i innych pomniejszych autorów. Tymczasem z faktu, że dzieła Shakespeare'a mają większą wartość literacką niż teksty Scribe'a, wcale nie wynika, że wystawienia sztuk tego pierwszego były lepsze lub ważniejsze dla ówczesnych widzów niż inscenizacje sztuk tego drugiego. Literaturocentryczne nastawienie wpłynęło także na hierarchie aktorów w historii teatru. Nie brakowało w XIX wieku przedstawień zachwycających publiczność i krytyków, z popisowymi kreacjami tak wielkich gwiazd, jak Józefa Ledóchowska, Ignacy Werowski, Leontyna Halpertowa, Wojciech Piasecki, Ludwik Panczykowski czy Alojzy Żółkowski, tylko ani te przedstawienia, ani ci artyści nie mieli tyle szczęścia, co Hamlet i Modrzejewska.

Nie bez znaczenia jest też to, że książki są, a przedstawień nie ma. Dlatego sami możemy ocenić, ile Shakespeare'a jest w Shakespearze Ostrowskiego, a wiedzę o przedstawieniu z 1871 czerpiemy głównie z recenzji. Czego nie zapisano, tego nie ma. $\mathrm{W}$ dodatku, zgodnie $\mathrm{z}$ ówczesnymi obyczajami, recenzenci omawiali przede wszystkim treść sztuki, a dopiero w dalszej kolejności, czasem marginalnie, zajmowali się tym, co nie jest literaturą, lecz teatrem (głównie grą aktorów). Nie pomoże nam też ikonografia, bo rycin i fotografii jest niewiele. Nawet tak ,twarde fakty”, jak egzemplarz reżyserski Hamleta okazują się migotliwe, choćby dlatego, że notatek dokonano w czterech kolorach i nie można ostatecznie ustalić, kto nanosił poszczególne poprawki - reżyser? cenzor? Królikowski?

W perspektywie teatralnej wydaje się, że przedstawienie Hamleta w 1871 było nieudane, ale informacje mamy niepełne, a głosy krytyków są niejednoznaczne. Opinię o wadze tej inscenizacji narzucił nam Józef Szczublewski - w najlepszej wierze i na podstawie materiałów źródłowych, interpretowanych jednak w duchu kultu Shakespeare'a i Modrzejewskiej. Większość z nas podziela ten podwójny kult, dlatego odruchowo jesteśmy skłonni podkreślać historyczną wagę przedstawienia, chociaż jako dzieło teatralne raczej na to nie zasługuje.

W dodatku kiepsko znamy tło, na którym się pojawiło. Zbyt słabo i wyrywkowo - jak dotąd - przebadany został polski teatr w okresie międzypowstaniowym, czyli w latach 1830-1863 ${ }^{113}$. Na szczęście coraz więcej przedstawień ma już swo-

113 Szczególnie dotkliwie odczuwałam te braki, pracując nad książką: H. Waszkiel, Trudne lata. Teatr warszawski 1815-1868, Warszawa 2015. 
je wnikliwe i wielostronne portrety ${ }^{114}$. Wciąż jednak setki inscenizacji czekają na opisanie i dopóki tego nie uczynimy, atrakcyjność narracji badacza, jak w przypadku opowieści Szczublewskiego, będzie przesądzała o naszym wyobrażeniu o teatrze XIX wieku. Recenzje, opisy oraz legendy opowiadają własne historie, potrzeba nam jednak krytycznego opracowania źródeł oraz ogólnego i możliwie pełnego tła, na którym różne narracje zderzałyby się ze sobą.

114 Zamawiają je u różnych autorów redaktorzy Encyklopedii Teatru Polskiego (http://encyklopediateatru.pl, dział „Przedstawienia”) i opisów wciąż przybywa. Wszystkie realizacje Makbeta omawia J. Komorowski, Piramida zbrodni. „Makbet” w kulturze polskie 1790-1989, Warszawa 2002. Siedem wybranych spektakli opisała E. Partyga, Wiek XIX. Przedstawienia, Warszawa 2016. Znakomite opisy trzech oper, w tym słynnego Roberta Diabła z 1837, sporządziła A. Borkowska-Rychlewska, Poema muzykalne. Studia o operze w Polsce w okresie romantyzmu, Kraków 2006. Wiele obserwacji przynosi seria Polska dramatyczna 2. Dramat i dramatyzacje w XVIII $i$ XIX wieku, red. M. Sugiera, Kraków 2014. Wiele informacji o warszawskich przedstawieniach XIX w. znajdziemy w pracach D. Ratajczakowej czy D. Kosińskiego. Przykłady można by mnożyć, niemniej obszar białych plam nadal pozostaje rozległy. 